\title{
Pengungkapan Corporate Social Responsibility, Kinerja Lingkungan dan Nilai Perusahaan
}

\author{
Ida Ayu Yuni Pramitha ${ }^{1}$ \\ Fakultas Ekonomi dan Bisnis \\ Universitas Udayana, Indonesia
}

\author{
I Putu Sudana ${ }^{2}$ \\ Fakultas Ekonomi dan Bisnis \\ Universitas Udayana, Indonesia
}

Surel : idaayuyunipramitha@yahoo.com

\section{ABSTRAK}

Nilai perusahaan merupakan indikator kinerja yang penting bagi perusahaan-perusahaan go-public. Penelitian ini bertujuan untuk mengkaji secara empiris pengaruh pengungkapan corporate social responsibility dan kinerja lingkungan pada nilai perusahaan. Penelitian ini dilakukan pada perusahaan consumer goods yang terdaftar di Bursa Efek Indonesia dan mengikuti pemeringkatan Program Penilaian Peringkat Kinerja Perusahaan. Kriteria inklusi sampel ditentukan dengan teknik purposive sampling. Data yang diperoleh dianalisis dengan teknik Regresi Linear Berganda. Penelitian ini menemukan bahwa pengungkapan corporate social responsibility berpengaruh positif pada nilai perusahaan, selaras dengan agency theory, legitimacy theory, dan stakeholder theory. Kinerja lingkungan ditemukan tidak berpengaruh pada nilai perusahaan. Penelitian ini merekomendasikan pentingnya intensitas pengungkapan sebagai bagian dari strategi manajemen dalam meningkatkan nilai perusahaan.

Kata Kunci: Pengungkapan Corporate Social Responsibility; Kinerja Lingkungan; Nilai Perusahaan.

\section{Corporate Social Responsibility Disclosure, Environmental Performance and Firm Value}

\begin{abstract}
Firm value is an important performance indicator for publicly-listed companies. The purpose of this study is to empirically examine the effect of corporate social responsibility disclosure and environmental performance on firm value. Companies in consumer goods listed in Indonesia Stock Exchange are chosen as the focus of the study. Additionally, companies should participate in the Company Performance Assessment Program ranking. Sample is determined by a purposive sampling and data are analyzed with Multiple Linear Regression Analysis. This study concludes that corporate social responsibility disclosure has positive effect on firm value, implying conformity with agency theory, legitimacy theory, and stakeholder theory. Environmental performance is found has no effect on firm value. Practically, this study recommends that intensity of disclosure should be considered as an important part of management strategy in increasing firm value.
\end{abstract}

Keywords: Corporate Social Responsibility Disclosure; Environmental Performance; Firm Value.

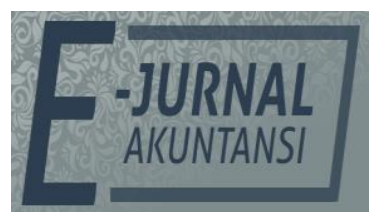

e-ISSN 2302-8556

Vol. 31 No. 3

Denpasar, Maret 2021

Hal. 615-634

DOI:

10.24843/EJA.2021.v31.i03.p08

PENGUTIPAN:

Pramitha, I.A.Y., \& Sudana, I P. (2021). Pengungkapan Corporate Social Responsibility,

Kinerja Lingkungan dan

Nilai Perusahaan. E-Jurnal Akuntansi, 31(3), 615-634

RIWAYAT ARTIKEL: Artikel Masuk: 27 Mei 2020 Artikel Diterima: 28 Juli 2020

Artikel dapat diakses : https://ojs.unud.ac.id/index.php/Akuntansi/index 


\section{PENDAHULUAN}

Keberadaan sebuah perusahaan go public tidak dapat terlepas dari upaya-upaya yang dilakukannya dalam meningkatkan nilai perusahaan. Nilai perusahaan adalah persepsi investor atas keberhasilan perusahaan dalam mengelola sumber dayanya pada akhir tahun berjalan yang ditunjukkan dari harga saham (Darmastika \& Ratnadi, 2019). Nilai perusahaan dijadikan sebagai fokus utama bagi investor dalam pengambilan keputusan untuk berinvestasi di perusahaan (Budiharjo, 2019). Bagi manajemen, upaya-upaya memaksimalkan nilai perusahaan merupakan suatu hal yang sangat penting, karena memaksimalkan nilai perusahaan sama artinya dengan memaksimalkan kekayaan pemegang saham (Hirdinis, 2019). Tujuan perusahaan bisa tercapai dengan adanya pelaksanaan fungsi manajemen keuangan yang tepat, karena setiap keputusan keuangan yang diambil akan berpengaruh terhadap keputusan manajemen keuangan lainnya dan akan berdampak pada nilai perusahaan (Sari \& Sedana, 2020).

Nilai perusahaan merupakan indikator penting bagi investor dalam menilai sebuah perusahaan sebelum mengambil keputusan-keputusan investasi, maka dengan tingginya nilai perusahaan menunjukkan kesuksesan perusahaan dalam memakmurkan para investornya (Mardiana \& Wuryani, 2019). Nilai perusahaan yang ditunjukkan dari harga sahamnya merupakan alat ukur bagi pihak-pihak yang memiliki kepentingan untuk mengetahui bagaimana image perusahaan di mata publik, saat publik menilai harga saham perusahaan lebih tinggi dari harga bukunya, maka hal tersebut merepresentasikan tingginya nilai suatu perusahaan (Bella \& Suaryana, 2017). Salah satu indikator yang bisa digunakan untuk mengukur nilai perusahaan adalah rasio Tobin's Q. Rasio Tobin's Q dapat menunjukkan proforma manajemen dalam mengelola aset perusahaan (Sudiyatno \& Puspitasari, 2010). Rasio Tobin's Q dinilai mampu memberikan informasi yang paling baik karena bisa menjelaskan beragam fenomena dalam kegiatan perusahaan (Mareta \& Fitriyah, 2017).

Ketatnya persaingan dunia bisnis turut serta mendorong perusahaan go public, termasuk perusahaan manufaktur, untuk terus mempertahankan kelangsungan usahanya dalam jangka panjang dengan cara meningkatkan nilai perusahaannya. Perusahaan manufaktur adalah perusahaan berskala besar yang terdiri dari tiga sektor yaitu, sektor industri dasar dan kimia, sektor aneka industri, serta sektor industri barang konsumsi. Sektor industri barang konsumsi atau consumer goods adalah salah satu sektor dari perusahaan manufaktur yang berperan aktif di pasar modal Indonesia dan masih menjadi pilihan utama investor dalam menanamkan dananya serta termasuk investasi yang menjanjikan di Indonesia (Amelia \& Asmara, 2019). Sektor consumer goods juga memiliki peran yang penting dalam upaya menyejahterakan kehidupan masyarakat, karena produknya digunakan untuk kebutuhan hidup sehari-hari serta dapat bertahan menghadapi krisis moneter (Febriyanti \& Yahya, 2017). Hal tersebut kemungkinan besar yang membuat sektor industri consumer goods cenderung lebih diminati investor dan menjadikan sektor industri consumer goods sebagai sarana untuk melakukan investasi jangka panjang.

Walaupun sektor industri consumer goods dianggap memiliki keunggulan jika dibandingkan dengan dua sektor lainnya dalam lingkup perusahaan 
manufaktur, tetapi fenomena yang terjadi tidak selalu konsisten dengan anggapan tersebut. Kinerja saham sektor industri consumer goods pada tahun 2018 melemah sebesar 10,21 persen, ketika dua sektor lainnya menunjukkan penguatan. Sektor industri dasar dan kimia menguat sebesar 24,01 persen sedangkan sektor aneka industri menguat sebesar 0,96 persen (Wareza, 2018). Tabel 1 menunjukkan perbedaan kinerja saham pada indeks sektoral perusahaan manufaktur tahun 2018 yang memperlihatkan bahwa kinerja saham sektor industri consumer goods adalah yang paling lemah jika dibandingkan dengan dua sektor lainnya. Fenomena tersebut menunjukkan bahwa meskipun produk dari sektor industri consumer goods begitu dekat dengan masyarakat, namun belum menjamin bahwa sektor ini akan terus konsisten mengalami peningkatan kinerja saham setiap tahunnya.

Tabel 1. Kinerja Saham Indeks Sektoral Tahun 2018 pada Perusahaan Manufaktur

\begin{tabular}{lccc}
\hline \multicolumn{1}{l}{ Indeks Sektor Manufaktur } & Nilai Terakhir & Perubahan & $\%$ \\
\hline $\begin{array}{l}\text { Industri dasar dan kimia } \\
\text { (Basic-Ind) }\end{array}$ & 854,733 & 165.514 & $24,01 \%$ \\
$\begin{array}{l}\text { Aneka Industri } \\
\text { (Misc-Ind) }\end{array}$ & $1.394,428$ & 13.251 & $0,96 \%$ \\
$\begin{array}{l}\text { Industri Konsumsi } \\
\text { (Consumer) }\end{array}$ & $2.569,287$ & -292.104 & $-10,21 \%$ \\
\hline $\begin{array}{l}\text { Sumber: } \text { www.finansialku.com, 2019 } \\
\text { (2) }\end{array}$ & &
\end{tabular}

Sumber: www.finansialku.com, 2019

Fenomena yang terjadi pada perusahaan consumer goods secara lebih spesifik ditunjukan oleh nilai perusahaannya yang mengalami fluktuasi setiap tahunnya. Situasi tersebut bisa disimak dari grafik rata-rata nilai perusahaan sektor ini selama periode 2016-2018 (Gambar 1).

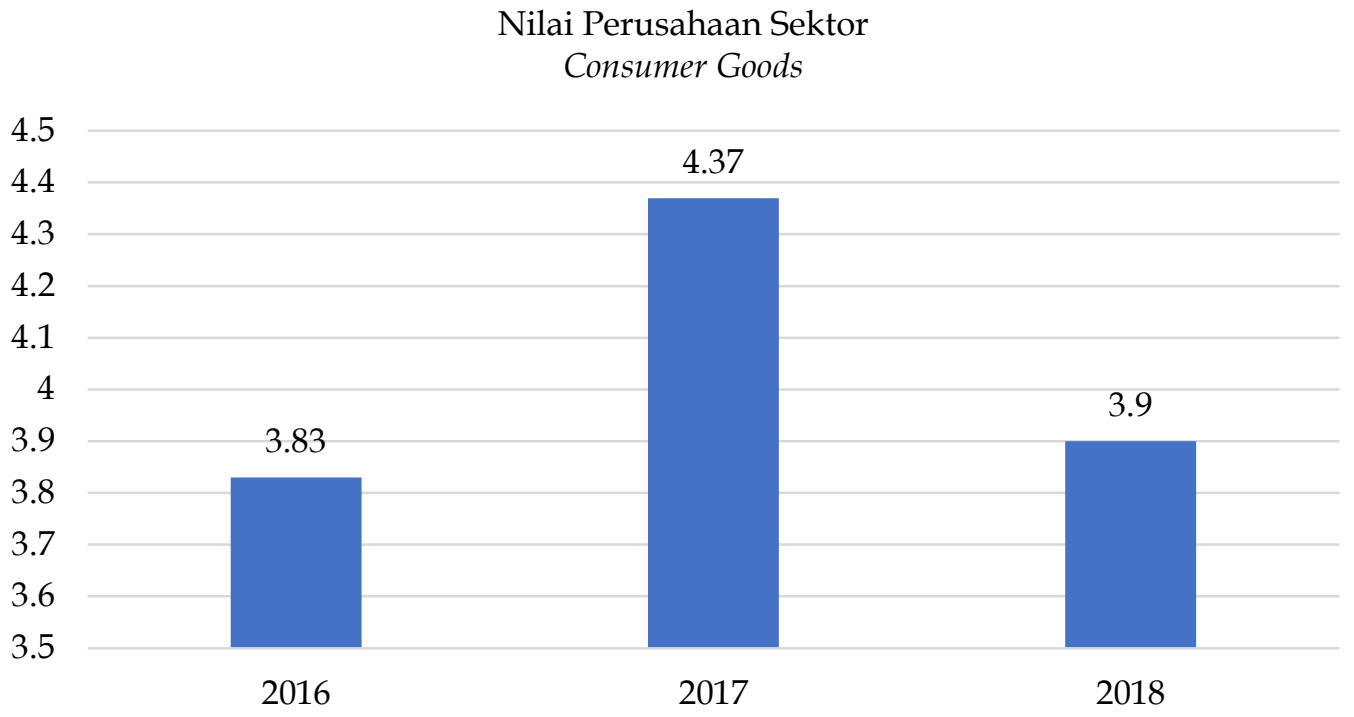

Gambar 1. Grafik Nilai Perusahaan Sektor Industri Consumer Goods di BEI Periode 2016-2018

Sumber : Data Penelitian, 2019

Grafik dalam gambar 1 menunjukkan bahwa rata-rata nilai perusahaan sektor industri consumer goods dari tahun 2016-2018 mengalami fluktuasi. Pada tahun 2016 rata-rata nilai perusahaannya sebesar 3,83, kemudian tahun 2017 
meningkat menjadi 4,37, dan mengalami penurunan kembali pada tahun 2018 menjadi 3,9. Fluktuasi nilai perusahaan tersebut biasanya dikaitkan dengan informasi yang dimiliki oleh investor yang sebagian besar bersumber dari publikasi manajemen. Dalam mengelola perusahaan, manajer dituntut agar dapat memenuhi ekspektasi dari para investor, sedangkan investor tentunya berharap agar harga saham yang terus mengalami peningkatan, sehingga manajer dituntut untuk dapat mengelola perusahaan dengan baik agar harga saham perusahaan tidak menurun (Hamidah et al.,2018).

Konflik kepentingan dapat terjadi antara manajer dengan investor yang dikenal sebagai agency conflict. Jensen \& Meckling (1976) menandaskan bahwa konflik keagenan muncul karena adanya perbedaan kepentingan antara manajer selaku agent dengan pemilik modal selaku principal. Agent sebagai pihak yang memiliki lebih banyak informasi terkait dengan kondisi perusahaan pada saat sekarang dan mendatang tidak akan memberikan semua informasi tersebut kepada principal, sedangkan di sisi lain, principal memerlukan informasi komprehensif mengenai kondisi perusahaan dalam pengambilan keputusankeputusan investasi (Hidayanti \& Sunyoto, 2012). Berpedoman pada agency theory, salah satu bentuk conflict of interest yang dapat terjadi antara manajemen dan investor hadir dalam bentuk asimetri informasi. Informasi yang kurang diperoleh pihak luar berkaitan dengan kondisi perusahaan dapat membuat para investor melindungi diri dengan cara memberikan harga yang rendah atau menarik investasi mereka dari saham perusahaan (Anjani \& Astika, 2018).

Principal meyakini pentingnya informasi dalam pengambilan keputusan yang optimal. Salah satu upaya untuk mengatasi asimetri informasi dapat dilakukan dengan menampilkan pengungkapan (disclosure). Melalui pengungkapan, informasi privat yang awalnya hanya diketahui oleh manajemen dapat berkembang menjadi informasi publik yang juga tersedia bagi para pemangku kepentingan lainnya, sehingga dapat mengatasi atau setidaknya mengurangi kondisi asimetri informasi dan dapat membantu investor untuk melakukan valuasi atas sebuah perusahaan (Hung et al., 2013). Pengungkapan sukarela (voluntary disclosure) dalam laporan tahunan merupakan cara yang dapat dilakukan perusahaan untuk meminimalisasi terjadinya asimetri informasi. Pengungkapan sukarela juga membuat para pengguna laporan keuangan akan memiliki informasi yang semakin lengkap dalam memahami kegiatan operasional perusahaan serta dapat menghadirkan transparansi pengelolaan sebuah perusahaan (Darma \& Irwanto, 2017).

Salah satu bentuk pengungkapan sukarela yang dapat diberikan oleh perusahaan kepada para investor adalah dengan cara menyajikan informasi tambahan berupa pengungkapan Corporate Social Responsibility (CSR) dalam laporan tahunannya. Corporate Social Responsibility merupakan bentuk kepedulian perusahaan dalam menjaga legitimasi dan reputasi perusahaan (Kusumawardani \& Sudana, 2017). Perusahaan akan mendapatkan legitimasi dari masyarakat melalui pengungkapan CSR yang akan berdampak pada kelangsungan hidup perusahaan itu sendiri (Damayanthi, 2019). Tanggung jawab sosial perusahaan telah menjadi bagian integral dalam praktik bisnis, sehingga banyak perusahaan yang mendedikasikan satu bagian dari laporan tahunan dan situs web perusahaannya untuk kegiatan CSR (Servaes \& Tamayo, 2013). CSR selain dapat 
mengurangi asimetri informasi dalam internal perusahaan, investor, dan pemangku kepentingan lainnya, tujuan dari CSR juga untuk meningkatkan kesejahteraan sosial dan standar hidup secara keseluruhan (Chen \& Lee, 2017).

Beberapa penelitian terdahulu yang mengkaji pengaruh pengungkapan CSR pada nilai perusahaan menunjukkan hasil yang belum konsisten. Murnita \& Putra (2018), Wijaya \& Wirawati (2019), serta Damayanthi (2019) menemukan bahwa pengungkapan CSR berpengaruh positif pada nilai perusahaan. Hasil tersebut tidak sejalan dengan temuan penelitian Inastri \& Mimba (2017) yang mendapatkan hasil bahwa pengungkapan CSR tidak berpengaruh pada nilai perusahaan. Sabatini \& Sudana (2019) mendapatkan hasil bahwa pengungkapan CSR berpengaruh negatif pada nilai perusahaan. Sabatini \& Sudana (2019) memberikan argumentasi bahwa ketika perusahaan melakukan aktivitas CSR dan melakukan pengungkapan maka perusahaan harus mengeluarkan biaya tambahan, sebuah kondisi yang dianggap merugikan investor jangka pendek.

Keinginan sebuah entitas bisnis dalam meningkatkan nilai perusahaan mendorongnya untuk melakukan berbagai cara tanpa terkecuali menciptakan kinerja lingkungan agar semakin terlihat baik dimata masyarakat, khususnya investor. Perusahaan yang memerhatikan kinerja lingkungannya dengan baik secara tidak langsung telah menjaga kelangsungan usahanya dalam jangka panjang, sehingga dapat terhindar dari kerugian yang timbul di masa mendatang (Ulya \& Prastiwi, 2014). Aktivitas bisnis yang ramah lingkungan juga dapat meningkatkan citra perusahaan, dan dengan begitu perusahaan akan diakui sebagai perusahaan yang peduli terhadap lingkungan hidup (Utomo et al., 2019).

Pentingnya aspek kinerja lingkungan mendapatkan perhatian yang serius dari Pemerintah Indonesia. Melalui Kementerian Lingkungan Hidup dan Kehutanan (KLHK), Pemerintah telah menyelenggarakan Program Penilaian Peringkat Kinerja Perusahaan (lebih dikenal dengan PROPER). Salah satu yang menjadi tolak ukur bahwa perusahaan telah mematuhi peraturan terkait dengan kewajiban pelestarian lingkungan adalah dari hasil PROPER yang didapatkan oleh perusahaan, yang terdiri dari peringkat emas (sangat-sangat baik), hijau (sangat baik), biru (baik), merah (buruk) serta hitam (sangat buruk) (Arieftiara \& Venusita, 2017). Hasil dari PROPER diumumkan secara berkala oleh Pemerintah kepada masyarakat sehingga masyarakat dapat mengetahui bagaimana tingkat pengelolaan lingkungan yang telah dilakukan oleh perusahaan dengan melihat warnanya saja (Budiharjo, 2019). Dipahami dengan teori legitimasi, perusahaan harus memiliki kinerja lingkungan yang baik sebagai upayanya dalam mewujudkan organisasi yang peduli pada lingkungan sekitar (Kusuma \& Dewi, 2019). Dengan demikian, melalui kinerja lingkungan yang baik dari perusahaan, maka dapat menambah kepercayaan publik khususnya investor untuk terus berinvestasi yang akan berdampak pada meningkatnya nilai perusahaan.

Beberapa penelitian terdahulu telah melakukan kajian mengenai pengaruh kinerja lingkungan pada nilai perusahaan. Simpulan dari penelitian-penelitian tersebut masih beragam. Penelitian yang dilakukan oleh Kurnia \& Wirasedana (2018), Rahayu \& Wirakusuma (2019), serta Kusuma \& Dewi (2019) menemukan bahwa kinerja lingkungan berpengaruh positif pada nilai perusahaan. Hasil tersebut tidak sejalan dengan temuan penelitian Pratiwi \& Setyoningsih (2014) 
serta Mareta \& Fitriyah (2017) yang menyimpulkan bahwa kinerja lingkungan tidak berpengaruh terhadap nilai perusahaan.

Berdasarkan deskripsi dalam latar belakang masalah dan didukung oleh masih terjadinya inkonsistensi temuan-temuan penelitian terdahulu menjadikan penelitian ini penting dilakukan. Berbeda dengan beberapa penelitian-penelitian terdahulu, studi ini menggunakan kedua variabel, yakni pengungkapan CSR dan kinerja lingkungan secara bersama-sama sebagai variabel prediktor. Hal ini ditujukan untuk memeroleh bukti empiris pengaruh pengungkapan corporate social responsibility dan kinerja lingkungan pada nilai perusahaan khususnya pada perusahaan-perusahaan sektor consumer goods.

Studi ini mengadopsi Agency Theory sebagai payung konseptualnya. Menurut Jensen \& Meckling (1976), dalam sebuah kontrak keagenan terdapat potensi konflik keagenan yang diakibatkan oleh adanya perbedaan kepentingan antara manajer selaku agent dengan pemilik modal selaku principal. Perbedaan kepentingan mengakibatkan adanya perbedaan kebutuhan informasi perusahaan antara pemegang saham (principal) dengan pengelola perusahaan (agent). Terjadinya ketidakseimbangan akses informasi antara pengelola perusahaan dengan pemegang saham dapat menimbulkan suatu kondisi yang disebut asimetri informasi (Lisa, 2012).

Keadaan asimetri informasi jika dibiarkan secara terus menerus dapat menyebabkan turunnya minat investor untuk berinvestasi sehingga berpengaruh pada harga saham yang berdampak pada menurunnya nilai perusahaan. Dengan demikian, maka diperlukan upaya untuk mengatasi asimetri informasi tersebut. Salah satu upaya yang dapat dilakukan adalah melalui pengungkapan sukarela dalam laporan tahunan perusahaan. Selain pengungkapan wajib mengenai laporan keuangan, perusahaan juga melakukan pengungkapan sukarela untuk menarik investor dengan informasi privat yang disediakan untuk para pemangku kepentingan sehingga dapat memberikan nilai tambah bagi perusahaan dan juga untuk menunjukkan kredibilitas sebuah perusahaan. Diadopsinya konsep pengungkapan sukarela, terutama untuk pengungkapan berkualitas tinggi, dapat menawarkan transparansi yang diperlukan agar dapat diandalkan dan dapat dibandingkan dengan pengungkapan dari perusahaan lain (Hummel \& Schlick, 2016).

Salah satu bentuk pengungkapan sukarela yang dilakukan perusahaan adalah pengungkapan corporate social responsibility (CSR). Penyajian informasi mengenai CSR diharapkan dapat mengurangi asimetri informasi karena perusahaan menyediakan informasi pada aspek ekonomi, sosial dan lingkungan (Ronald et al., 2019). CSR adalah bentuk tanggung jawab dari perusahaan dalam mengatasi masalah sosial dan lingkungan yang diakibatkan dari kegiatan operasional perusahaan, oleh karena itu CSR berperan besar dalam meningkatkan nilai perusahaan (Rosiana et al., 2013). CSR dapat dijadikan alat marketing baru bagi perusahaan jika dilakukan secara berkelanjutan (Wulandari et al., 2016). Perusahaan yang menerapkan CSR secara berkelanjutan akan membantu dalam pengembangan masyarakat serta membangun citra dan reputasi perusahaan (Pascua, 2020). Perusahaan yang memiliki reputasi yang baik akan meningkatkan preferensi konsumen terhadap produk atau layanan yang ditawarkan sehingga 
hal tersebut dapat meningkatkan minat investor terhadap perusahaan (Mursitama et al., 2019).

Sejalan dengan pemikiran dalam teori legitimasi bahwa perusahaan harus berkontribusi dan memberikan manfaatnya kepada masyarakat, dengan melakukan program CSR dimana perusahaan tersebut melakukan kegiatan usahanya, sehingga perusahaan akan memeroleh legitimasi dari masyarakat. Komitmen perusahaan terhadap praktik CSR dapat membantu meyakinkan para pemangku kepentingan tentang niat perusahaan yang tulus untuk kebaikan bersama serta untuk mendapatkan legitimasi (Singh et al.,2017). Konsep tanggung jawab sosial juga berhubungan dengan teori stakeholder, dimana tanggung jawab perusahaan tidak hanya terbatas untuk memaksimalkan keuntungan dan kepentingan investor, namun juga harus memerhatikan konsumen, masyarakat, pemerintah, serta pemasok sebagai bagian dari operasi perusahaan tersebut (Lingga \& Wirakusuma, 2019). Sesuai dengan asumsi dasar dari teori stakeholder bahwa perusahaan tidak dapat melepaskan diri dari lingkungan sosialnya (Prihatiningtias \& Dayanti, 2014). Kegiatan sosial yang dilakukan oleh perusahaan sangat penting untuk dikomunikasikan dengan baik kepada pemegang saham, karena hal tersebut akan meningkatkan nilai perusahaan (Siahaan et al., 2020).

Pernyataan ini didukung oleh penelitian-penelitian terdahulu mengenai pengaruh pengungkapan CSR pada nilai perusahaan, yaitu Wijaya \& Wirawati (2019), Damayanthi (2019) serta Putra \& Astika (2019) yang mendapatkan hasil bahwa pengungkapan CSR berpengaruh positif terhadap nilai perusahaan. Argumen-argumen yang telah dikemukakan digunakan sebagai landasan dalam merumuskan hipotesis pertama.

$\mathrm{H}_{1}$ : Pengungkapan corporate social responsibility berpengaruh positif pada nilai perusahaan

Teori legitimasi didasari dari adanya hubungan antara perusahaan dan masyarakat. Teori legitimasi berfokus pada hubungan perusahaan dengan masyarakat yang bisa dilihat melalui kebijakan yang dikeluarkan oleh Pemerintah (Hardiyansah \& Agustini, 2020). Teori legitimasi menjadi sebuah landasan bagi perusahaan untuk peduli dengan apa yang menjadi harapan masyarakat dan bisa menyelaraskan nilai-nilai dengan norma sosial yang ada di masyarakat di tempat sebuah perusahaan tersebut beroperasi (Lingga \& Wirakusuma, 2019). Semakin baik peringkat kinerja lingkungan dari perusahaan, maka semakin baik juga bentuk tanggung jawab perusahaan terhadap lingkungan, sehingga hal tersebut dapat menarik minat investor untuk berinvestasi pada perusahaan yang mempunyai legitimasi di masyarakat (Kurnia \& Wirasedana 2018). Sebuah perusahaan akan tertinggal jika tidak dapat bersaing dengan perusahaan lain dalam batasan sosialnya yang ditandai dengan pertanggungjawaban lingkungan yang semakin meningkat (Sarumpaet, 2005).

Pendapat ini juga didukung oleh penelitian-penelitian terdahulu mengenai pengaruh kinerja lingkungan pada nilai perusahaan. Lingga \& Suaryana (2017) yang menyatakan bahwa kinerja lingkungan berpengaruh positif pada nilai perusahaan. Kusuma \& Dewi (2019) serta Kurnia \& Wirasedana (2018) juga mendapatkan hasil bahwa kinerja lingkungan berpengaruh positif pada nilai perusahaan. Kinerja lingkungan yang semakin baik dari perusahaan dapat menarik para investor karena telah memperoleh kepercayaan yang lebih dari 
masyarakat sehingga bisa meningkatkan nilai perusahaan (Kurnia \& Wirasedana, 2018).

Dalam membuat keputusan untuk berinvestasi, investor dipandang perlu memerhatikan faktor kinerja lingkungan. Dengan adanya kepedulian terhadap kinerja lingkungan, maka perusahaan juga akan mendapat citra yang baik dari masyarakat (Harahap et al., 2018). Dengan kinerja lingkungan yang baik dari keberadaan entitas bisnis maka diyakini dapat memberikan dampak yang baik pula bagi kelangsungan bisnis dalam jangka panjang (Haninun et al., 2019). Apabila kinerja lingkungannya baik, maka akan membuat investor tertarik menanamkan sahamnya di perusahaan tersebut sehingga menyebabkan nilai perusahaan menjadi meningkat. Berdasarkan uraian tersebut, maka dapat dirumuskan hipotesis kedua.

$\mathrm{H}_{2}$ : Kinerja lingkungan berpengaruh positif pada nilai perusahaan

\section{METODE PENELITIAN}

Tujuan dari penelitian ini adalah untuk memeroleh bukti empiris pengaruh pengungkapan corporate social responsibility dan kinerja lingkungan pada nilai perusahaan. Sejalan dengan tujuan tersebut, desain penelitian yang diadopsi dalam studi ini adalah pendekatan kuantitatif yang bersifat asosiatif. Penelitian ini dilakukan pada perusahaan-perusahaan sektor consumer goods yang terdaftar di Bursa Efek Indonesia (BEI). Data diperoleh dengan mengakses website resmi BEI yaitu website IDX (Indonesia Stock Exchange). Obyek dari penelitian ini adalah nilai perusahaan pada perusahaan consumer goods yang terdaftar di Bursa Efek Indonesia tahun 2016-2018.

Variabel dependen dalam penelitian ini adalah nilai perusahaan (Y). Nilai perusahaan diukur menggunakan rumus Tobin's $Q$. Tobin's $Q$ merupakan rasio nilai pasar aset perusahaan (diukur menggunakan nilai pasar dari saham yang beredar ditambah dengan total utang perusahaan) terhadap replacement cost aset perusahaan (Sabatini \& Sudana, 2019). Keunggulan dari rasio Tobin's Q sebagai proksi nilai perusahaan adalah memasukkan semua unsur utang dan modal saham perusahaan, tidak hanya saham biasa dan ekuitas perusahaan saja melainkan seluruh aset perusahaan (Chairunnisa, 2019). Rumus Tobins' $Q$ adalah sebagai berikut.

$$
\mathrm{Q}=\frac{\mathrm{MVE}+\mathrm{DEBT}}{\mathrm{TA}}
$$

Keterangan:

Q : Nilai perusahaan

MVE : Market Value of Equity/nilai pasar ekuitas

DEBT : Total utang

TA : Total aktiva

Variabel-variabel independen dalam penelitian ini adalah pengungkapan corporate social responsibility $\left(\mathrm{X}_{1}\right)$ dan kinerja lingkungan $\left(\mathrm{X}_{2}\right)$. Pengungkapan CSR diukur dengan menggunakan pedoman pengungkapan ISO 26000 yang memuat 37 item pengungkapan informasi (ISO 26000, 2010). Dalam pengukuran item-item pengungkapan ISO 26000 digunakan cara dummy, yaitu setiap kategori informasi pengungkapan CSR dalam instrumen penelitian diberi nilai 0 apabila kategori informasi tidak diungkapkan dalam laporan tahunan dan diberi nilai 1 jika 
kategori informasi diungkapkan dalam laporan tahunan (Sabatini \& Sudana, 2019). Variabel pengungkapan corporate social responsibility (CSRD) dihitung dengan rumus berikut.

$$
\text { CSRD }=\frac{\text { Jumlah item informasi CSR yang diungkapkan }}{37 \text { item informasi CSR menurut ISO } 26000}
$$

Variabel kinerja lingkungan diukur melalui prestasi perusahaan dalam mengikuti PROPER yang diselenggarakan oleh Kementerian Lingkungan Hidup dan Kehutanan. Kinerja lingkungan diukur menggunakan skor sesuai peringkat warna PROPER. Perusahaan yang memeroleh peringkat tertinggi yaitu emas, maka akan diberi skor 5, peringkat warna hijau diberi skor 4, peringkat warna biru diberi skor 3, peringkat warna merah diberi skor 2, serta peringkat terendah yaitu hitam diberi skor 1 (Kusuma \& Dewi, 2019). Kategori dan skor pemeringkatan PROPER disajikan dalam Tabel 2.

Tabel 2. Peringkat Kinerja PROPER

\begin{tabular}{lcc}
\hline Warna & Peringkat & Skor \\
\hline Emas & Sangat sangat baik & 5 \\
Hijau & Sangat baik & 4 \\
Biru & Baik & 3 \\
Merah & Buruk & 2 \\
Hitam & Sangat buruk & 1 \\
\hline
\end{tabular}

Sumber : Kusuma \& Dewi, 2019

Jenis data yang digunakan dalam penelitian ini adalah data kuantitatif berupa angka-angka mengenai total aset, total liabilitas, dan kapitalisasi pasar serta jumlah item pengungkapan CSR yang diperoleh dari laporan tahunan perusahaan sektor consumer goods yang terdaftar di Bursa Efek Indonesia (BEI) tahun 2016-2018. Data kuantitatif dalam penelitian ini juga berupa skor perusahaan consumer goods yang sesuai dengan kategori peringkat warna dalam PROPER. Sumber data dalam penelitian ini adalah data sekunder berupa data time series yang diperoleh dengan mengunduh laporan tahunan perusahaanperusahaan sektor consumer goods yang terdaftar di BEI tahun 2016-2018 yang tersaji dalam situs resmi BEI yaitu Indonesia Stock Exchange (IDX). Data laporan pemeringkatan PROPER diperoleh dari publikasi dalam situs resmi ProperKementerian Lingkungan Hidup dan Kehutanan.

Populasi dalam penelitian ini adalah perusahaan-perusahaan sektor consumer goods yang terdaftar di BEI dari tahun 2016-2018. Alasan dipilihnya sektor industri consumer goods adalah karena perusahaan tersebut dianggap paling tahan banting dan produknya mencakup kebutuhan hidup sehari-hari atau kebutuhan pokok sehingga mampu merepresentasikan seberapa besar tingkat konsumsi masyarakat. Sektor consumer goods juga relatif rentan dengan isu lingkungan karena berhubungan langsung dengan sumber daya alam dalam proses produksinya menghasilkan barang jadi. Sektor ini rawan untuk terjadinya pencemaran lingkungan yang diakibatkan dari adanya limbah jika tidak diatasi dengan baik. Dengan demikian, perusahaan consumer goods dianggap memiliki dampak yang cukup besar pada aspek sosial dan lingkungan. Kriteria inklusi sampel ditentukan menggunakan metode non-probability sampling dengan teknik purposive sampling. Adapun kriteria inklusi yang digunakan adalah perusahaan sektor consumer goods yang (1) terdaftar di BEI tahun 2016-2018, (2) perusahaan yang mempublikasikan laporan tahunan secara terus menerus di web BEI selama 
tahun penelitian 2016-2018 dan (3) mengikuti program pemeringkatan PROPER pada periode penelitian. Berdasarkan kriteria inklusi ini, maka diperoleh 56 amatan sebagai sampel penelitian. Seluruh data yang dibutuhkan dalam penelitian ini dikumpulkan dengan metode dokumentasi.

Data yang terkumpul dianalisis dengan mengadopsi teknik Analisis Regresi Linear Berganda. Pengujian ini tepat digunakan untuk mengetahui ada atau tidaknya pengaruh pengungkapan corporate social responsibility $\left(\mathrm{X}_{1}\right)$ dan kinerja lingkungan $\left(\mathrm{X}_{2}\right)$ pada nilai perusahaan $(\mathrm{Y})$. Adapun rumus persamaan regresi linear berganda yang digunakan dalam penelitian ini yaitu sebagai berikut.

$Y=\alpha+\beta_{1} X_{1}+\beta_{2} X_{2}+\varepsilon$

Keterangan :

$\mathrm{Y} \quad=$ Nilai Perusahaan

a $\quad=$ Konstanta

$\beta_{1-} \beta_{2}=$ Koefisien Regresi

$\mathrm{X}_{1} \quad=$ Pengungkapan Corporate Social Responsibility

$\mathrm{X}_{2} \quad=$ Kinerja Lingkungan

$\varepsilon \quad=$ Error Term, yang merupakan tingkat kesalahan penduga

\section{HASIL DAN PEMBAHASAN}

Sesuai dengan kriteria inklusi yang ditetapkan, jumlah sampel dalam penelitian ini adalah 56 amatan. Dalam Tabel 3, disajikan hasil pengujian statistik deskriptif yang telah dilakukan. Deskripsi statistik disajikan untuk memberikan informasi deskriptif mengenai karakteristik-karakteristik penting variabel-variabel penelitian, yaitu jumlah sampel, nilai minimum, nilai maksimum, nilai mean (ratarata), dan standar deviasi.

Tabel 3. Hasil Uji Statistik Deskriptif

\begin{tabular}{llllll}
\hline & $\mathrm{N}$ & Minimum & Maximum & Mean & Std. Deviation \\
\hline CSRD & 56 & 0,16 & 0,70 & 0,4261 & 0,11462 \\
Kinerja Lingkungan & 56 & 2 & 4 & 3,12 & 0,574 \\
Nilai Perusahaan & 56 & 0,66 & 23,29 & 4,0518 & 5,00270 \\
Valid N (listwise) & 56 & & & & \\
\hline Sum
\end{tabular}

Sumber : Data Penelitian, 2020

Variabel pengungkapan CSR menunjukkan bahwa sampel penelitian berjumlah 56. Nilai minimum variabel pengungkapan CSR sebesar 0,16, sedangkan nilai maksimum sebesar 0,70. Nilai mean (rata-rata) pada pengungkapan CSR sebesar 0,4261, nilai rata-rata tersebut cenderung mendekati nilai maksimum yang memiliki arti bahwa perusahaan consumer goods telah melakukan pengungkapan CSR dengan baik. Nilai standar deviasi pengungkapan CSR sebesar 0,11462, nilai tersebut lebih rendah dari nilai mean (rata-rata) yang menunjukkan bahwa pengungkapan CSR persebaran datanya telah merata.

Distribusi frekuensi pengungkapan CSR disajikan pada Tabel 4, menunjukkan bahwa frekuensi variabel pengungkapan CSR paling banyak terletak pada interval 0,36-0,45 yaitu sebanyak 20 atau sebesar 35,7 persen dan paling sedikit terletak pada interval 0,56-0,65 yaitu sebanyak 1 atau sebesar 1,8 persen. Data dalam tabel seluruhnya valid, maka pada kolom valid percent nilainya sama dengan yang terdapat pada kolom percent. Pada kolom cumulative percent, nilai kumulatif berikutnya didapatkan dari penjumlahan nilai pertama dengan 
kedua yang ada dalam valid percent, begitu juga seterusnya hingga mendapatkan nilai kumulatif akhir 100 persen.

Tabel 4. Distribusi Frekuensi Pengungkapan CSR

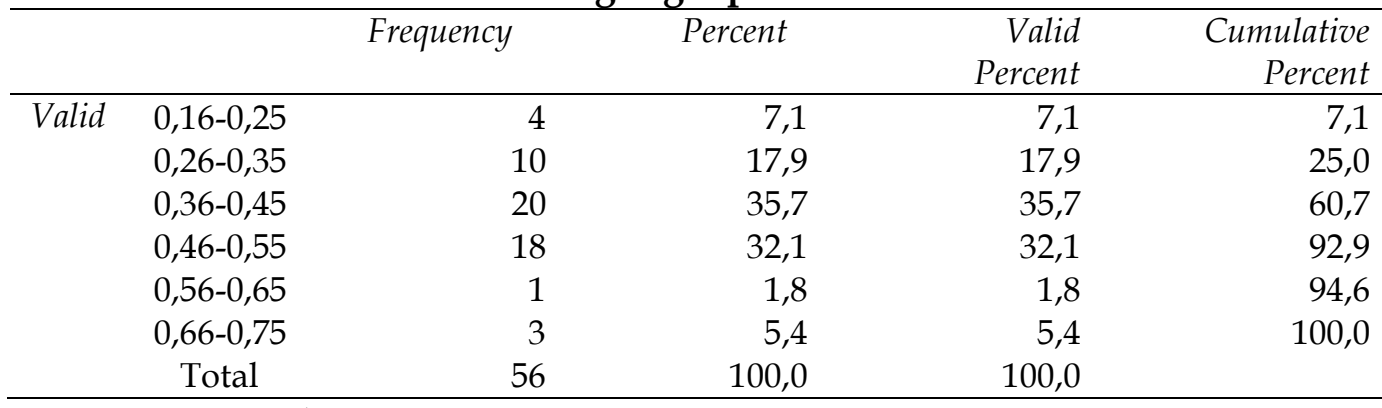

Sumber : Data Penelitian, 2020

Variabel kinerja lingkungan menunjukkan bahwa sampel penelitian berjumlah 56. Nilai minimum variabel kinerja lingkungan adalah sebesar 2. Nilai maksimum kinerja lingkungan adalah sebesar 4. Nilai mean (rata-rata) pada kinerja lingkungan sebesar 3,12, nilai rata-rata tersebut cenderung mendekati nilai maksimum berarti bahwa kinerja lingkungan perusahaan consumer goods tergolong baik. Nilai standar deviasi pada kinerja lingkungan sebesar 0,574 menunjukkan bahwa kinerja lingkungan persebaran datanya telah merata, karena nilai standar deviasi lebih rendah dari nilai rata-rata. Distribusi frekuensi kinerja lingkungan disajikan pada Tabel 5 .

Tabel 5. Distribusi Frekuensi Kinerja Lingkungan

\begin{tabular}{llllll}
\hline & Frequency & Persent & $\begin{array}{l}\text { Valid } \\
\text { Percent }\end{array}$ & $\begin{array}{l}\text { Cumulative } \\
\text { Percent }\end{array}$ \\
\hline Valid & 2 & 6 & 10,7 & 10,7 & 10,7 \\
& 3 & 37 & 66,1 & 66,1 & 76,8 \\
& 4 & 13 & 23,2 & 23,2 & 100,0 \\
& Total & 56 & 100,0 & 100,0 & \\
\hline
\end{tabular}

Sumber : Data Penelitian, 2020

Berdasarkan Tabel 5, diketahui bahwa frekuensi variabel kinerja lingkungan paling banyak dengan skor 3 yaitu sebanyak 37 atau sebesar 66,1 persen, sedangkan yang paling sedikit yaitu skor 2 sebanyak 6 atau sebesar 10,7 persen. Data dalam Tabel 5, seluruhnya valid, maka pada kolom valid percent nilainya sama dengan yang terdapat pada kolom percent, sementara pada bagian cumulative percent terlihat skor 2 sebesar 10,7 persen, skor 3 sebesar 76,8 persen, dan skor 4 sebesar 100 persen. Nilai 76,8 persen merupakan nilai kumulatif dari penjumlahan 10,7 persen dengan 66,1 persen yang ada dalam valid percent, sedangkan nilai 100 persen merupakan nilai kumulatif dari penjumlahan 76,8 persen dengan 23,2 persen.

Variabel nilai perusahaan menunjukkan bahwa sampel penelitian berjumlah 56. Nilai minimum variabel nilai perusahaan sebesar 0,66. Nilai maksimum pada variabel nilai perusahaan sebesar 23,29. Nilai mean (rata-rata) pada nilai perusahaan sebesar 4,0518, nilai rata-rata tersebut cenderung mendekati nilai minimum yang memiliki arti bahwa nilai perusahaan consumer goods tergolong rendah. Nilai standar deviasi pada nilai perusahaan sebesar 5,00270, nilai tersebut lebih tinggi dari nilai rata-rata yang menunjukkan bahwa nilai 
perusahaan persebaran datanya kurang merata. Distribusi frekuensi variabel nilai perusahaan disajikan pada Tabel 6 .

Tabel 6. Distribusi Frekuensi Nilai Perusahaan

\begin{tabular}{ccllll}
\hline & Frequency & Persent & $\begin{array}{l}\text { Valid } \\
\text { Percent }\end{array}$ & $\begin{array}{l}\text { Cumulative } \\
\text { Percent }\end{array}$ \\
\hline Valid & $0,66-4,65$ & 45 & 80,4 & 80,4 & 80,4 \\
& $4,66-8,65$ & 2 & 3,6 & 3,6 & 83,9 \\
& $8,66-12,65$ & 5 & 8,9 & 8,9 & 92,9 \\
$12,66-16,65$ & 1 & 1,8 & 1,8 & 94,6 \\
$16,66-20,65$ & 2 & 3,6 & 3,6 & 98,2 \\
$20,66-24,65$ & 1 & 1,8 & 1,8 & 100,0 \\
& Total & 56 & 100,0 & 100,0 & \\
\hline
\end{tabular}

Sumber: Data Penelitian, 2020

Tabel 6, menunjukkan bahwa frekuensi variabel nilai perusahaan paling banyak terletak pada interval 0,66 - 4,65 yaitu sebanyak 45 atau sebesar 80,4 persen dan paling sedikit terletak pada interval 12,66 - 16,65 dan interval 20,66 - 24,65 yaitu masing-masing sebanyak 1 atau sebesar 1,8 persen.Data dalam Tabel 6, seluruhnya valid, maka pada kolom valid percent nilainya sama dengan yang terdapat pada kolom percent, sementara pada kolom cumulative percent untuk nilai kumulatif berikutnya didapatkan dari penjumlahan nilai pertama dengan kedua yang ada dalam valid percent, begitu juga seterusnya hingga mendapatkan nilai kumulatif akhir yaitu 100 persen.

Teknik analisis data yang digunakan dalam penelitian ini adalah analisis regresi linier berganda. Penggunaan analisis ini mensyaratkan dilakukannya pengujian atas asumsi-asumsi klasik yang harus dipenuhi, meliputi uji normalitas, uji multikolinearitas, uji heteroskedastisitas, serta uji autokorelasi. Tabel 7, merupakan rangkuman dari pengujian atas asumsi-asumsi klasik.

Tabel 7. Rangkuman Uji Asumsi Klasik

\begin{tabular}{|c|c|c|c|c|c|}
\hline \multirow{3}{*}{$\begin{array}{c}\mathrm{Uji} \\
\text { Normalitas }\end{array}$} & \multirow[t]{3}{*}{ Variabel } & \multirow{2}{*}{\multicolumn{2}{|c|}{$\begin{array}{c}\text { Uji } \\
\text { Multikolinearitas }\end{array}$}} & \multirow{3}{*}{$\begin{array}{c}\text { Uji } \\
\text { Heteroskedastisitas }\end{array}$} & \multirow{3}{*}{$\begin{array}{c}\text { Uji } \\
\text { Autokorelasi }\end{array}$} \\
\hline & & & & & \\
\hline & & Tolerance & VIF & & \\
\hline \multirow{2}{*}{$\begin{array}{c}\text { Signifikansi }= \\
0,151\end{array}$} & CSI & 0,822 & 1,217 & 0,060 & $\mathrm{DW}=1,678$ \\
\hline & Kinerja Lingkungan & 0,822 & 1,217 & 0,421 & \\
\hline
\end{tabular}

Sumber : Data Penelitian, 2020

Uji normalitas dilakukan dengan menggunakan uji Kolmogorov-Smirnov. Berdasarkan pengujian tersebut diperoleh hasil uji seperti yang tersaji dalam Tabel 7. Dengan nilai signifikansi sebesar 0,151 dan taraf signifikansi lebih besar dari 0,05 dapat disimpulkan bahwa data yang digunakan dalam penelitian ini berdistribusi normal.

Berdasarkan hasil uji multikolinearitas yang disajikan dalam Tabel 7, nilai tolerance untuk semua variabel bebas $>0,10$ yaitu CSR sebesar 0,822 dan kinerja lingkungan sebesar 0,822. Nilai VIF seluruh variabel bebas $<10$ yaitu CSR sebesar 1,217 dan kinerja lingkungan sebesar 1,217. Berdasarkan nilai tolerance dan VIF tersebut maka dapat disimpulkan bahwa tidak terjadi multikolinearitas dalam penelitian ini.

Berdasarkan hasil uji heteroskedastisitas yang disajikan dalam Tabel 7, diketahui bahwa nilai signifikansi variabel pengungkapan CSR adalah sebesar 0,060 dan nilai signifikansi varibel kinerja lingkungan sebesar 0,421. Kedua nilai 
tersebut lebih besar dari 0,05 yang berarti bahwa tidak terjadi heteroskedastisitas dalam penelitian ini.

Berdasarkam hasil uji autokorelasi yang disajikan dalam Tabel 7 menunjukkan bahwa nilai Durbin-Watson (DW) yaitu sebesar 1,678. Dalam tabel Durbin-Watson (DW) dengan taraf signifikansi 5\%, jumlah sampel sebanyak 56 dan terdapat 2 variabel bebas, maka diperoleh nilai $\mathrm{dL}$ (batas bawah) $=1,4954$ dan nilai $\mathrm{dU}$ (batas atas) $=1,6430$ serta $4-\mathrm{dU}=2,357$. Dengan demikian diperoleh hasil uji autokorelasi yaitu 1,6430<1,678 < 2,357 sesuai kriteria dalam uji DurbinWatson, $\mathrm{dU}<\mathrm{d}<4-\mathrm{dU}$, maka dapat disimpulkan bahwa tidak ada gejala autokorelasi dalam penelitian ini.

Analisis regresi linier berganda merupakan pengujian yang dilakukan untuk mengetahui pengaruh atas dua atau lebih variabel bebas terhadap variabel terikat. Pengujian ini untuk mengetahui ada tidaknya pengaruh pengungkapan corporate social responsibility $\left(\mathrm{X}_{1}\right)$ dan kinerja lingkungan $\left(\mathrm{X}_{2}\right)$ pada nilai perusahaan $(Y)$. Hasil analisis regresi linier berganda pada penelitian ini ditampilkan dalam Tabel 8.

Tabel 8. Analisis Regresi Linear Berganda

\begin{tabular}{|c|c|c|c|c|c|c|}
\hline \multirow{2}{*}{\multicolumn{2}{|c|}{ Model }} & \multicolumn{2}{|c|}{$\begin{array}{l}\text { Unstandardized } \\
\text { Coefficients }\end{array}$} & \multirow{2}{*}{$\begin{array}{c}\text { Standardized } \\
\text { Coefficients } \\
\text { Beta }\end{array}$} & \multirow[b]{2}{*}{$\mathrm{t}$} & \multirow[b]{2}{*}{ Sig. } \\
\hline & & $\bar{B}$ & Std. Error & & & \\
\hline \multirow[t]{3}{*}{1} & & $-5,430$ & 2,699 & & $-2,012$ & 0,049 \\
\hline & & 34,491 & 4,518 & 0,790 & 7,635 & 0,000 \\
\hline & ngan & $-1,668$ & 0,902 & $-0,191$ & $-1,850$ & 0,070 \\
\hline & 0,516 & & & & & \\
\hline & 30,291 & & & & & \\
\hline & $0,000^{\mathrm{b}}$ & & & & & \\
\hline
\end{tabular}

Sumber : Data Penelitian, 2020

Berdasarkan Tabel 8, diperoleh model regresi linear berganda pada penelitian ini sebagai berikut.

$$
\mathrm{Y}=-5,430+34,491 \mathrm{X}_{1}-1,668 \mathrm{X}_{2}+\varepsilon
$$

Nilai konstanta sebesar $-5,430$ bermakna bahwa jika nilai pengungkapan CSR dan kinerja lingkungan sama dengan 0 , maka nilai perusahaan adalah sebesar $-5,430$ satuan.

Nilai koefisien regresi variabel pengungkapan corporate social responsibility $\left(\beta_{1}\right)$ adalah sebesar 34,491. Koefisien regresi tersebut memiliki nilai positif yang artinya bahwa apabila pengungkapan CSR meningkat sebesar satu satuan, maka nilai perusahaan akan meningkat sebesar 34,491 satuan dengan asumsi variabel lainnya adalah konstan.

Nilai koefisien regresi variabel kinerja lingkungan $\left(\beta_{2}\right)$ sebesar $-1,668$. Koefisien regresi tersebut memiliki nilai negatif yang artinya bahwa apabila kinerja lingkungan meningkat sebesar satu satuan, maka nilai perusahaan akan turun sebesar 1,668 satuan dengan asumsi variabel lainnya adalah konstan.

Penelitian ini menggunakan nilai dari adjusted $\mathrm{R}^{2}$ yang bisa dilihat pada Tabel 8, bahwa nilai adjusted $\mathrm{R}^{2}$ yaitu sebesar 0,516 atau 51,6\%. Hal tersebut menunjukkan bahwa variansi nilai perusahaan dapat dijelaskan oleh variabel pengungkapan CSR dan kinerja lingkungan sebesar 51,6\%, sedangkan sisanya 
sebesar $48,4 \%$ dapat dijelaskan oleh faktor-faktor lain yang tidak dimasukkan ke dalam penelitian ini.

Berdasarkan Tabel 8, diperoleh nilai F hitung sebesar 30,291 dengan nilai signifikansi $F$ yaitu sebesar 0,000. Nilai signifikansi $F$ lebih kecil dari level signifikansi 0,05, sehingga dapat dikatakan bahwa model penelitian ini layak digunakan.

Berdasarkan hasil uji statistik t seperti yang tersaji dalam Tabel 8, diperoleh nilai signifikansi variabel pengungkapan CSR sebesar 0,000, nilai ini lebih kecil dari level signifikansi 0,05 dan nilai koefisien regresi sebesar 34,491. Hasil pengujian tersebut memiliki arti bahwa pengungkapan CSR berpengaruh positif pada nilai perusahaan. Dengan demikian $\mathrm{H}_{0}$ ditolak dan $\mathrm{H}_{1}$ diterima. Hal tersebut menjadi bukti empiris, bahwa semakin tingginya pengungkapan CSR yang dilakukan perusahaan, maka nilai perusahaan pun akan semakin meningkat. Hasil penelitian ini sejalan dengan teori keagenan, dimana konflik kepentingan antara principal dengan agent yang bisa menimbulkan asimetri informasi, dapat berkurang dengan cara melakukan pengungkapan. Konflik keagenan bisa dikurangi dengan memperkecil asimetri informasi melalui adanya pengungkapan yang lebih luas (Rahindayati et al., 2015). Salah satu bentuk pengungkapan yang bisa dilakukan oleh perusahaan adalah pengungkapan corporate social responsibility (CSR) yang terdapat dalam laporan tahunan perusahaan. Sejalan juga dengan teori legitimasi, semakin meningkatnya intensitas pengungkapan CSR maka akan semakin meningkatkan nilai perusahaan tersebut karena perusahaan akan mendapatkan legitimasi dari masyarakat apabila mampu menciptakan hubungan yang harmonis dengan masyarakat. Hasil penelitian ini juga selaras dengan pemikiran dalam teori stakeholder bahwa perusahaan yang melakukan kegiatan CSR dan mengungkapkan di dalam laporan tahunannya maka dapat memperkuat dan membangun relasi yang lebih baik dengan para stakeholder, karena perusahaan bukan sebagai entitas yang berdiri hanya untuk kepentingan pribadi perusahaan itu sendiri. Kegiatan CSR dari perusahaan dapat ditujukan untuk membangun hubungan yang baik dengan eksternal stakeholder seperti komunitas, pelanggan, dan calon karyawan (Mansaray et al., 2017). Hasil penelitian ini juga sejalan dengan penelitian yang dilakukan oleh Anjani dan Astika (2018), Wijaya \& Wirawati (2019), Darmastika \& Ratnadi (2019) serta Damayanthi (2019) yang juga mendapatkan hasil bahwa pengungkapan Corporate Social Responsibility berpengaruh positif pada nilai perusahaan.

Berdasarkan hasil uji statistik $\mathrm{t}$, diperoleh nilai signifikansi variabel kinerja lingkungan sebesar 0,070, nilai ini lebih besar dari level signifikansi 0,05 dan nilai koefisien regresi sebesar $-1,668$. Hasil pengujian tersebut memiliki arti bahwa kinerja lingkungan tidak berpengaruh pada nilai perusahaan. Dengan demikian $\mathrm{H}_{0}$ diterima dan $\mathrm{H}_{1}$ ditolak. Hasil penelitian ini tidak berhasil membuktikan berlakunya teori legitimasi sebagai teori yang mendukung dalam variabel kinerja lingkungan, karena kinerja lingkungan yang baik dari perusahaan belum bisa menambah kepercayaan investor untuk terus berinvestasi pada sebuah perusahaan. Investor mungkin tidak semua berfokus pada kinerja lingkungan sebagai topik utama yang perlu dipertimbangkan dalam mengambil keputusan berinvestasi. Hal tersebut juga kemungkinan disebabkan oleh perilaku oportunistik investor dengan melihat perusahaan dari aspek ekonominya saja, 
sehingga informasi penting dari kinerja lingkungan tidak begitu diperhatikan. Variabilitas kinerja lingkungan yang juga kurang variatif atau perusahaan dominan mendapatkan peringkat 3 (Biru) dan 4 (Hijau), sehingga perusahaan yang mendapatkan peringkat 2 (Merah) kemungkinan cenderung diabaikan oleh investor sebagai pertimbangan dalam melakukan investasi. Dengan demikian, hal tersebut menyebabkan kinerja lingkungan yang diterapkan oleh suatu perusahaan belum dapat memengaruhi nilai perusahaan. Hasil penelitian ini sejalan dengan penelitian yang dilakukan oleh Pratiwi \& Setyoningsih (2014), Mareta \& Fitriyah (2017) serta Tjahjono (2013) yang menyatakan bahwa kinerja lingkungan tidak berpengaruh terhadap nilai perusahaan.

Implikasi teoretis dalam penelitian ini yaitu secara teoretis mendukung berlakunya teori keagenan yang menjelaskan hubungan antara principal dengan agen, dimana konflik kepentingan yang dapat memunculkan terjadinya asimetri informasi dapat diminimalisir dengan adanya pengungkapan sukarela dari perusahaan. Penelitian ini juga sesuai dengan teori legitimasi dan teori stakeholder untuk variabel pengungkapan CSR bahwa apabila perusahaan mampu menciptakan hubungan yang baik dengan masyarakat, maka legitimasi masyarakat pun akan meningkat serta perusahaan dapat memberikan manfaat kepada seluruh stakeholder, karena stakeholder cukup mempunyai andil yang besar dalam keikutsertaannya menjaga lingkungan dan perusahaan bukan suatu entitas yang hanya beroperasi untuk kepentingan perusahaan itu sendiri. Implikasi kebijakan bagi perusahaan untuk terus melakukan pengungkapan CSR dalam laporan tahunan, karena CSR merupakan salah satu strategi dalam meningkatkan nilai perusahaan dan menarik minat investor. Perusahaan perlu menerapkan pedoman sebagai acuan dalam melaksanakan dan mengungkapkan CSR agar bisa diterima dengan baik oleh masyarakat khususnya investor.

Penelitian ini juga memberikan implikasi bagi perusahaan agar memperbaiki dan meningkatkan pelaksanaan kinerja lingkungannya secara berkesinambungan sehingga dapat meminimalisasi dampak dari aktivitas operasinya dan akan mendapatkan respon yang baik dari masyarakat. Implikasi bagi investor yaitu membantu investor dalam memeroleh informasi mengenai kondisi perusahaan setelah melakukan pengungkapan CSR dan kinerja lingkungan sehingga bisa dijadikan pertimbangan dalam berinvestasi pada perusahaan tersebut.

\section{SIMPULAN}

Berdasarkan hasil pembahasan yang telah dipaparkan, maka dapat disimpulkan bahwa pengungkapan corporate social responsibility berpengaruh positif pada nilai perusahaan consumer goods yang terdaftar di Bursa Efek Indonesia dan mengikuti peringkat PROPER periode 2016-2018, sedangkan kinerja lingkungan tidak berpengaruh pada nilai perusahaan consumer goods yang terdaftar di Bursa Efek Indonesia dan mengikuti peringkat PROPER periode 2016-2018.

Adapun saran yang dapat diajukan dalam penelitian ini, yaitu bagi peneliti selanjutnya direkomendasikan agar tidak terbatas hanya pada satu jenis industri saja, namun jika memungkinkan agar dapat memperluas cakupan jenis industri ataupun menggunakan seluruh perusahaan yang terdaftar di BEI dan mengikuti 
peringkat PROPER agar hasilnya lebih representative dan mampu mencerminkan keadaan kinerja lingkungan yang sebenarnya.

Bagi manajemen perusahaan, diharapkan agar kedepannya meningkatkan item pengungkapan CSR karena terbukti dapat meningkatkan nilai perusahaan dan perusahaan juga agar tetap menerapkan kinerja lingkungan dengan baik walaupun tidak berpengaruh pada nilai perusahaan, namun hal tersebut harus tetap dijalankan karena orientasi perusahaan pada saat sekarang dan di masa yang akan datang tidak hanya berfokus pada shareholder melainkan juga kepada stakeholder serta untuk membuktikan bahwa perusahaan juga peduli dengan lingkungan di sekitarnya. Hal ini selaras dengan teori stakeholder bahwa perusahaan bukanlah suatu entitas yang semata hanya menjalankan usahanya untuk kepentingan perusahaan saja, melainkan juga harus memberikan manfaat kepada seluruh stakeholder-nya.

Bagi investor diharapkan agar tidak hanya memerhatikan perusahaan dari segi ekonominya saja melainkan juga menjadikan pengungkapan CSR dan kinerja lingkungan sebagai referensi dalam pengambilan keputusan berinvestasi sehingga bisa mendapatkan hasil yang terbaik dan prospek yang menjanjikan kedepannya.

\section{REFERENSI}

Amelia, Y., \& Asmara, R. Y. (2019). The Effect of Current Ratio , Debt to Equity Ratio and Return in The Consumer Goods Industry Sector Listed in Indonesia Stock Exchange 2012-2017. INTERNATIONAL HUMANITIES and APPLIED SCIENCES JOURNAL (IHASJ), 2(2), 30-37

Anjani, N., \& Astika, I. B. P. (2018). Pengaruh Pengungkapan Corporate Social Responsibility pada Nilai Perusahaan dengan Likuiditas Perusahaan sebagai Pemoderasi. E-Jurnal Akuntansi Universitas Udayana, 24(2), 899-928. https:/ / doi.org/10.24843/EJA.2018.v24.i02.p04

Arieftiara, D., \& Venusita, L. (2017). Pengaruh Kinerja Lingkungan dan Intensitas Persaingan terhadap Nilai Perusahaan dalam rangka Mendukung Sustainability Development Goals. Conference Paper Universitas Negeri Surabaya, 1-20.

Bella, L. K. G., \& Suaryana, I. G. N. A. (2017). Pengaruh IOS dan Pengungkapan CSR Pada Nilai Perusahaan dengan Pertumbuhan Perusahaan sebagai Variabel Pemoderasi. E-Jurnal Akuntansi Universitas Udayana, 19 (1), 508-535. Retrieved from https://ojs.unud.ac.id/index.php/Akuntansi/article/view/27227

Budiharjo, R. (2019). Effect of Environmental Performance and Financial Performance on Firm Value. International Journal of Academic Research in Accounting, Finance and Management Sciences, 9(2), 65-73. https://doi.org/http://dx.doi.org/10.6007/IJARAFMS/v9-i2/6030

Bursa Efek Indonesia. (2019). Laporan Tahunan Perusahaan Tercatat. Diunduh dari website: www.idx.co.id. Diakses pada 18 Juli 2019.

Chairunnisa, R. (2019). Likuiditas, Aktivitas, dan Profitabilitas Terhadap Nilai Perusahaan Automotive yang Terdaftar di BEI. Jurnal Ekonomi Manajemen $\mathcal{E}$ Bisnis, 20 (2), 149-160. 
Chen, R. C. Y., \& Lee, C. H. (2017). The Influence of CSR on Firm Value: an Application of Panel Smooth Transition Regression on Taiwan. Applied Economics, $49 \quad$ (34), 3422-3434. https://doi.org/10.1080/00036846.2016.1262516

Damayanthi, I. G. A. E. (2019). Fenomena Faktor yang Mempengaruhi Nilai Perusahaan. Jurnal Ilmiah Akuntansi dan Bisnis, 14(2), 208-218. https://doi.org/10.24843/jiab.2019.v14.i02.p06

Darma, N. A., \& Irwanto, A. (2017). Luas Pengungkapan Sukarela, Asimetri Informasi, dan Biaya Modal Ekuitas. Jurnal Ekonomi dan Bisnis Universitas Airlangga, 27(1), 1-14. http://dx.doi.org/10.20473/jeba.V27I12017.5512

Darmastika, I. W. R., \& Ratnadi, N. M. D. (2019). Pengaruh Pengungkapan Corporate Social Responsibility pada Nilai Perusahaan Dengan Profitabilitas dan Leverage Sebagai Variabel Moderasi. E-Jurnal Akuntansi Universitas Udayana, 27(1), 362-387. https://doi.org/https://doi.org/10.24843/EJA.2019.v27.i01.p14

Febriyanti, A. D., \& Yahya. (2017). Pengaruh Ukuran Perusahaan, Profitabilitas, Likuiditas dan Pertumbuhan Penjualan Terhadap Struktur Modal. Jurnal Ilmu Dan Riset Manajemen, 6(5), 1-19.

Finansialku. (2019). Kinerja Saham 2018: IHSG Turun, namun 27 Emiten Cetak Return $>100 \%$ dalam Setahun +43 Perusahaan IPO Hasilkan Laba Positif. Diakses pada 20 Agustus 2019, dari https://www.finansialku.com/kinerjasaham-2018/.

Hamidah, H., Maryadi, S., \& Ahmad, G. N. (2018). Pengaruh Harga Saham, Volatilitas Harga Saham, dan Volume Perdagangan Saham terhadap Bid-Ask Spread Saham pada Perusahaan Sektor Pertambangan yang Terdaftar di ISSI Periode Juni 2016-Juni 2017. Jurnal Riset Manajemen Sains Indonesia, 9(1), 147169. https://doi.org/10.21009/jrmsi.009.1.10

Haninun, H., Lindrianasari, L., Sarumpaet, S., \& Komalasari, A. (2019). Does the Cost of Capital Affect Environmental Performance? Indonesian Journal of Sustainability Accounting and Management, 3(1), 14-21. https:// doi.org/10.28992/ijsam.v3i1.68

Harahap, C. D., Juliana, I., \& Lindayani, F. F. (2018). The Impact of Environmental Performance and Profitability on Firm Value. Indonesian Management and Accounting Research, 17(1), 53-70. https://doi.org/10.25105/imar.v17i1.4665

Hardiyansah, M., \& Agustini, A. T. (2020). Analysis Of Carbon Emissions Disclosure And Firm Value: Type of industry as a moderating model. International Journal of Scientific and Technology Research, 9(2), 1125-1132.

Hidayanti, E., \& Sunyoto. (2012). Pentingnya Pengungkapan (Disclosure) Laporan Keuangan dalam Meminimalisasi Asimetri Informasi. Jurnal WIGA, 2(2),1928.

Hirdinis, M. (2019). Capital Structure and Firm Size on Firm Value Moderated by Profitability. International Journal of Economics and Business Administration, 7(1), 174-191.

Hummel, K., \& Schlick, C. (2016). The relationship between sustainability performance and sustainability disclosure - Reconciling voluntary disclosure theory and legitimacy theory. Journal of Accounting and Public Policy, 35(5), 455-476. https://doi.org/10.1016/j.jaccpubpol.2016.06.001 
Hung, M., Shi, J., \& Wang, Y. (2013). The Effect of Mandatory CSR Disclosure on Information Asymmetry: Evidence from a Quasi-natural Experiment in China. SSRN Electronic Journal, 1-38. https:/ / doi.org/10.2139/ssrn.2206877

Inastri, M. A., \& Mimba, N. P. S. H. (2017). Pengaruh Penerapan Good Corporate Governance dan Pengungkapan Corporate Social Responsibility Pada Nilai Perusahaan. E-Jurnal Akuntansi Universitas Udayana, 21(2), 1400-1429. https:// doi.org/10.24843/EJA.2017.v21.i02.p20

ISO 26000. (2010). International Standard : Guidance on Social Responsibility (First Edition). Switzerland.

Jensen, M. C., \& Meckling, W. H. (1976). Theory of The Firm: Managerial Behavior, Agency Costs and Ownership Structure. Journal of Financial Economics, 3(4), 305-360.

Kurnia, A. D., \& Wirasedana, P. (2018). Pengaruh Kinerja Lingkungan dan Komponen Good Corporate Governance pada Nilai Perusahaan yang Terdaftar di BEI. E-Jurnal Akuntansi Universitas Udayana, 24(3), 1737-1767. https://doi.org/10.24843/ eja.2018.v24.i03.p04

Kusuma, I. M. E. W., \& Dewi, L. G. K. (2019). Pengaruh Kinerja Lingkungan pada Nilai Perusahaan dengan Good Corporate Governance Sebagai Variabel Pemoderasi. E-Jurnal Akuntansi Universitas Udayana, 26(3), 2183-2209. https://doi.org/10.24843/eja.2019.v26.i03.p19

Kusumawardani, I., \& Sudana, I. P. (2017). Faktor-Faktor Yang Memengaruhi Pengungkapan Corporate Social Responsibility. E-Jurnal Akuntansi Universitas Udayana, 19(1), 741-770.

Lingga, V. P., \& Wirakusuma, M. G. (2019). Pengaruh Corporate Social Responsibility pada Nilai Perusahaan dengan Kinerja Lingkungan Sebagai Pemoderasi. E-Jurnal Ekonomi Dan Bisnis Universitas Udayana, (8)4, 413-442. https:/ / doi.org/10.24843/ eeb.2019.v08.i04.p05

Lingga, W., \& Suaryana, I. G. N. A. (2017). Pengaruh Langsung dan Tidak Langsung Kinerja Lingkungan pada Nilai Perusahaan. E-Jurnal Akuntansi Universitas Udayana, 20(2), 1419-1445.

Lisa, O. (2012). Asimetri Informasi dan Manajemen Laba: Suatu Tinjauan Dalam Hubungan Keagenan. Jurnal WIGA, 2(1), 42-49. Retrieved from https://media.neliti.com/media/publications/36615-ID-asimetriinformasi-dan-manajemen-laba-suatu-tinjauan-dalam-hubungankeagenan.pdf

Mansaray, A. P., Yuanyuan, L., \& Brima, S. (2017). The Impact of Corporate Social Responsibility Disclosure on Financial Performance of Firms in Africa. International Journal of Economics and Financial Issues, 7(5), 137-146.

Mardiana, I. A., \& Wuryani, E. (2019). Pengaruh Kinerja Lingkungan Terhadap Nilai Perusahaan dengan Profitabilitas Sebagai Variabel Pemoderasi. AKUNESA : Jurnal Akuntansi Unesa,8(1).

Mareta, A., \& Fitriyah, F. K. (2017). Pengaruh Kinerja Lingkungan dan Kepemilikan Asing Terhadap Nilai Perusahaan (Studi Pada Perusahaan Manufaktur yang Mengikuti PROPER dan Terdaftar di Bursa Efek Indonesia Periode 2013-2015). Proceedings, 449-471.

Murnita, P. E. M., \& Putra, I. M. P. D. (2018). Pengaruh Corporate Social Responsibility terhadap Nilai Perusahaan dengan Profitabilitas dan Leverage 
Sebagai Variabel Pemoderasi. E-Jurnal Akuntansi Universitas Udayana, 23(2), 1470-1494. https://doi.org/10.24843/eja.2018.v23.i02.p25

Mursitama, T. N., Noerlina, \& Wulandari, N. B. (2019). The Study Of Corporate Social Responsibility In Emerging Economies: The Case Of SME's, Tourism, Environment Upgrade Programs In Indonesia. International Journal of Scientific and Technology Research, 8(6), 22-24.

Pascua, D. S. (2020). Sustainable Corporate Social Responsibility Practices Of Business Establishments In Region 2, Philippines. Journal of Critical Reviews, 7(11), 53-59. https:// doi.org/10.31838/jcr.07.11.08

Pratiwi, M. W., \& Setyoningsih, S. (2014). Pengaruh Kinerja Lingkungan Terhadap Nilai Perusahaan Dengan Corporate Social Responsibility Disclosure Sebagai Variabel Intervening. Media Riset Akuntansi, 4(2), 24-46.

Prihatiningtias, Y. W., \& Dayanti, N. (2014). Corporate Social Responsibility Disclosure and Firm Financial Performance in Mining and Natural Resources Industry. The International Journal of Accounting and Business Society, 22(1), 3559.

Proper-Kementerian Lingkungan Hidup dan Kehutanan. (2019). Program Penilaian Kinerja Perusahaan (PROPER). www.proper.menlhk.go.id. Diakses pada 20 Juli 2019.

Putra, I. B. A., \& Astika, I. B. P. (2019). Pengaruh Pengungkapan Corporate Social Responsibility pada Nilai Perusahaan Dengan Likuiditas Sebagai Variabel Moderasi. E-Jurnal Akuntansi Universitas Udayana, 26(1), 30-57. https://doi.org/10.24843/EJA.2019.v26.i01.p02

Rahayu, N. L. D., \& Wirakusuma, M. G. (2019). Pengaruh Kinerja Lingkungan, Good Corporate Governance, dan Kepemilikan Asing Terhadap Nilai Perusahaan Manufaktur. E-Jurnal Akuntansi Universitas Udayana, 29(2), 485502. https:// doi.org/10.24843/EJA.2019.v29.i02.p01

Rahindayati, N. M., Ramantha, I. W., \& Rasmini, N. K. (2015). Pengaruh Diversitas Pengurus pada Luas Pengungkapan Corporate Social Responsibility Perusahaan Sektor Keuangan. E-Jurnal Ekonomi dan Bisnis Universitas Udayana, 4(05), 312-330.

Ronald, S., Ng, S., \& Daromes, F. E. (2019). Corporate Social Responsibility as Economic Mechanism for Creating Firm Value. Indonesian Journal of Sustainability Accounting and Management, 3(1), 22-36. https://doi.org/10.28992/ijsam.v3i1.69

Rosiana, G. A. M. E., Juliarsa, G., \& Sari, M. M. R. (2013). Pengaruh Pengungkapan CSR Terhadap Nilai Perusahaan dengan Profitabilitas Sebagai Variabel Pemoderasi. E-Jurnal Akuntansi Universitas Udayana, 5(3), 723-738. https:// doi.org/10.21107/infestasi.v12i1.1797

Sabatini, K., \& Sudana, I. P. (2019). Pengaruh Pengungkapan Corporate Social Responsibility Pada Nilai Perusahaan Dengan Manajemen Laba Sebagai Variabel Moderasi. Jurnal Ilmiah Akuntansi dan Bisnis, 14(1), 56-69. https:// doi.org/10.24843/jiab.2019.v14.i01.p06

Sari, I. A. G. D. M., \& Sedana, I. B. P. (2020). Profitability and Liquidity on Firm Value and Capital Structure as Intervening Variable. International Research Journal of Management, IT $\mathcal{E}$ Social Sciences, 7(1), 116-127. https://doi.org/10.21744/irjmis.v7n1.828 
Sarumpaet, S. (2005). The Relationship Between Environmental Performance and Financial Performance of Indonesian Companies. Jurnal Akuntansi dan Keuangan, 7(2), 89-98. https:/ / doi.org/10.9744/jak.7.2.pp.\%2089-98

Servaes, H., \& Tamayo, A. (2013). The Impact of Corporate Social Responsibility on Firm Value: The Role Of Customer Awareness. Management Science, 59(5), 1045-1061. https://doi.org/10.1287/mnsc.1120.1630

Siahaan, Y., Susanti, E., \& Sudirman, A. (2020). Effect Of Firm Characteristics On Firm Value Through Triple Bottom Line Disclosure: Pharmaceutical Companies Listed On Indonesia Stock Exchange. International Journal of Scientific \& Technology Research, 9(2), 2228-2234

Singh, P. J., Sethuraman, K., \& Lam, J. Y. (2017). Impact of Corporate Social Responsibility Dimensions on Firm Value: Some Evidence from Hong Kong and China. Sustainability, 9(9), 1532. https:// doi.org/10.3390/su9091532

Sudiyatno, B., \& Puspitasari, E. (2010). Tobin's Q dan Altman Z-Score Sebagai Indikator Pengukuran Kinerja Perusahaan . Kajian Akuntansi, 2(1), 9-21.

Tjahjono, M.E.S. (2013). Pengaruh Kinerja Lingkungan Terhadap Nilai Perusahaan dan Kinerja Keuangan. Jurnal Ekonomi, 4(1), 38-46.

Ulya, M. A., \& Prastiwi, A. (2014). Pengaruh Corporate Governance Terhadap Kinerja Ekonomi Perusahaan dengan Kinerja Lingkungan Sebagai Variabel Intervening Studi Empiris pada Perusahaan yang Memperoleh Penilaian PROPER. Diponegoro Journal Of Accounting, 3(3), 1-14.

Utomo, M. N., Cahyaningrum, W., \& Kaujan. (2019). Does Green Business Improve Corporate Image And Firm Value? International Journal of Scientific $\mathcal{E}$ Technology Research, 8(12), 3106-3114

Wareza, M. (2018). Perdagangan Saham 2018 Usai, Kapitalisasi Tembus Rp 7.000 T. Diakses pada 20 Agustus 2019, dari https://www.cnbcindonesia.com/market/20181228182432-17-48390 / perdagangan-saham-2018-usai-kapitalisasi-tembus-rp-7000-t.

Wijaya, I. P. I., \& Wirawati, N. G. P. (2019). Good Corporate Governance Sebagai Pemoderasi Pengaruh Profitabilitas dan Corporate Social Responsibility pada Nilai Perusahaan. E-Jurnal Akuntansi Universitas Udayana, 26(2), 1436-1463. https://doi.org/10.24843/eja.2019.v26.i02.p22.

Wulandari, A. A., Ramantha, I. W., \& Wirakusuma, M. G. (2016). Dampak Moderasi Profitabilitas Terhadap Pengaruh Corporate Social Responsibility Pada Nilai Perusahaan Manufaktur. E-Jurnal Ekonomi dan Bisnis Universitas Udayana, 5(7), 1889-1918. 